\title{
Thrombospondins in the heart: potential functions in cardiac remodeling
}

\author{
Mark W. M. Schellings - Geert C. van Almen • \\ E. Helene Sage • Stephane Heymans
}

Received: 27 May 2009/Accepted: 27 August 2009 / Published online: 2 October 2009

(C) The Author(s) 2009. This article is published with open access at Springerlink.com

\begin{abstract}
Cardiac remodeling after myocardial injury involves inflammation, angiogenesis, left ventricular hypertrophy and matrix remodeling. Thrombospondins (TSPs) belong to the group of matricellular proteins, which are nonstructural extracellular matrix proteins that modulate cellmatrix interactions and cell function in injured tissues or tumors. They interact with different matrix and membranebound proteins due to their diverse functional domains. That the expression of TSPs strongly increases during cardiac stress or injury indicates an important role for them during cardiac remodeling. Recently, the protective properties of TSP expression against heart failure have been acknowledged. The current review will focus on the biological role of TSPs in the ischemic and hypertensive heart, and will describe the functional consequences of TSP polymorphisms in cardiac disease.
\end{abstract}

Keywords Matricellular proteins · Thrombospondin .

Heart failure $\cdot$ Hypertrophy $\cdot$ Myocardial infarction

\section{Abbreviations \\ ACE Angiotensin converting enzyme \\ Ang-2 Angiopoietin-2}

Mark W.M. Schellings and Geert C. van Almen contributed equally to this manuscript

M. W. M. Schellings • G. C. van Almen · S. Heymans $(\bowtie)$

Center for Heart Failure Research,

Cardiovascular Research Institute Maastricht (CARIM),

Maastricht University,

Universiteitssingel 50,

6229 ER Maastricht, The Netherlands

e-mail: s.heymans@cardio.unimaas.nl

E. H. Sage

Hope Heart Program,

Benaroya Research Institute at Virginia Mason,

Seattle, WA, USA

$\begin{array}{ll}\text { Ang-II }_{1} & \text { Angiotensin-II } \\ \text { AT }_{1} \text { R } & \text { Angiotensin type I receptor } \\ \text { AVP } & \text { Arginine-vasopressin } \\ \text { ECM } & \text { Extracellular matrix } \\ \text { ERK } & \text { Extracellular-regulated kinase } \\ \text { FAK } & \text { Focal adhesion kinase } \\ \text { HF } & \text { Heart failure } \\ \text { IAP } & \text { Integrin-associated protein } \\ \text { ILK } & \text { Integrin-linked kinase } \\ \text { LRP1 } & \text { Low density lipoprotein-related } \\ & \text { scavenger receptor } \\ \text { LVH } & \text { Left ventricular hypertrophy } \\ \text { MI } & \text { Myocardial infarction } \\ \text { MMP } & \text { Matrix metalloproteinase } \\ \text { NO } & \text { Nitric oxide } \\ \text { PAI } & \text { Plasminogen activator inhibitor } \\ \text { PI3K } & \text { Phosphatidyl inositol 3-kinase } \\ \text { RAS } & \text { Renin-angiotensin system } \\ \text { SHR } & \text { Spontaneously hypertensive rat } \\ \text { SNP } & \text { Single nucleotide polymorphism } \\ \text { TGF- } \beta_{1} & \text { Transforming growth factor } \beta_{1} \\ \text { TIMP } & \text { Tissue inhibitor of metalloproteinases } \\ \text { TSP } & \text { Thrombospondin } \\ \text { tTG } & \text { Tissue transglutaminase } \\ \text { VEGF } & \text { Vascular endothelial growth factor } \\ \text { VSMC } & \text { Vascular smooth muscle cell } \\ \text { WKY } & \text { Wistar-Kyoto } \\ \text { WT } & \text { Wild-type }\end{array}$

\section{Introduction}

Heart failure (HF) is a condition resulting from different cardiovascular diseases and is one of the leading causes of mortality in Western society (Braunwald 1997; Vasan 
et al. 1995; Weir et al. 2006). Acute myocardial infarction (MI), hypertensive heart disease, myocarditis, and genetic cardiomyopathies are diseases that involve extensive cardiac remodeling, and often result in an increased risk of developing HF. Cardiac dysfunction after injury or stress is the outcome of a complex interplay between environmental and mechanical forces, different cell types, and various molecular processes that determine cell behavior. In vivo and in vitro studies have identified different mechanisms like the renin-angiotensin system (RAS) (Rosenkranz 2004), integrin-signaling (Lal et al. 2009; Manso et al. 2006), and matrix remodeling (Spinale 2007), among many others implicated in the progression of HF.

The extracellular matrix (ECM) is a crucial system for maintaining strength and organization of the cardiac tissue, and cardiac cell communication. The ECM forms a complex meshwork composed of structural proteins (such as type I and III collagen), proteoglycans, glycosaminoglycans, and a basement membrane, which together are responsible for tissue strength and structure. Matricellular proteins are non-structural proteins with a minimal expression in the normal heart. However, their expression increases after injury, where they modulate cell function and behavior through regulation of cell-cell and cell-matrix interactions (Spinale 2007).

Alterations in ventricular shape, size and function take place during cardiac injury, a process termed remodeling [reviewed in (Spinale 2007; Swynghedauw 1999)]. Matricellular proteins appear to be key players during cardiac remodeling (Schellings et al. 2004). Animal experiments revealed that the matricellular proteins thrombospondin 1 (TSP-1) (Frangogiannis et al. 2005), thrombospondin 2 (TSP-2) (Schroen et al. 2004), osteopontin (Collins et al. 2004; Trueblood et al. 2001), periostin (Shimazaki et al. 2008), and SPARC (Schellings et al. 2009) all protect the heart from developing pump failure. Among the matricellular proteins, thrombospondins (TSPs) were highlighted as important players in the process of cardiac remodeling (Chatila et al. 2007). This review summarizes our current knowledge of the role of TSPs, in particular TSP-1 and TSP-2, in cardiac remodeling during hypertrophy and after MI (Table 1). It will elaborate the molecular characteristics of TSPs that may relate to their role in preventing HF (Figs. 1 and 2).

\section{Thrombospondins in cardiac homeostasis}

Although the expression of thrombospondins is low in the normal, unstressed heart, recent evidence suggests that they are important in modulating physiological angiogenesis and blood pressure (Isenberg et al. 2009b; Krady et al. 2008). Global deletion of TSP-1 resulted in significant increases in cardiac and skeletal muscle capillarity, which was associated with increased basal levels of vascular endothelial growth factor (VEGF) in TSP-1-null mice (Malek and Olfert Ph 2009). Together with the effects of TSP-1 on endothelial cell activity, this finding indicates that TSP-1 is important in regulating physiological angiogenesis. The influence of TSP-2 on physiological angiogenesis was demonstrated in a three-dimensional angiogenesis assay in which TSP-2 limited angiogenesis by decreasing gelatinolytic activity, and by accelerated recovery of blood flow in TSP-2-null mice after hind limb ischemia. Also, increased endothelial cell organization and migration was observed when these cells were cultured on TSP-2-null ECM. Thus, TSP-2 can inhibit physiological angiogenesis by limiting the gelatinolytic activity of endothelial cells and by its influence on ECM structure. In addition to the effects of TSPs on physiological angiogenesis, recent evidence suggests that TSP-1 is able to modulate nitric oxide (NO) controlled blood pressure via its receptor CD47/ integrin associated protein (CD47/IAP) (Isenberg et al. 2009b).

\section{Thrombospondins in hypertrophic cardiac remodeling}

Cardiac hypertrophy, an increase in heart muscle mass, reflects an adaptation of the myocardium in response to increased mechanical stress or volume overload. It occurs as a physiological response, often seen in athletes, or as a pathologic one, which is associated with maladaptive changes. Persistent pathological hypertrophy finally evolves in cardiac dysfunction and clinical HF. Apart from mechanical stress, various growth factors and other stimuli can induce cellular signaling events that lead to hypertrophy. Although cardiac myocytes play an important role in the hypertrophic process, other cell types such as fibroblasts, endothelial cells, and smooth muscle cells may also affect the hypertrophic response (Gupta et al. 2007).

The ECM plays an important role in hypertrophic remodeling by providing architectural support to the cardiac tissue, and mediating cell-ECM communication. Here, the different mechanisms by which TSPs may affect hypertrophic cardiac remodeling will be discussed.

Thrombospondin expression in cardiac hypertrophy

Expression of TSP-1, TSP-2, and TSP-3 was increased during heart failure in a model of hypertensive hypertrophic remodeling (Schroen et al. 2004) (Table 1). The homozygous renin transgenic TGR(mRen2)27 rat suffers from severe hypertension that leads to cardiac hypertrophy at 
Table 1 Expression of TSPs and cardiac phenotypes of different TSP null mice in cardiac pathologies

\begin{tabular}{|c|c|c|c|c|c|}
\hline & \multicolumn{2}{|c|}{ Expression } & \multicolumn{2}{|c|}{ TSP null cardiac phenotype } & \multirow[t]{2}{*}{ References } \\
\hline & $\begin{array}{l}\text { Pressure } \\
\text { overload }\end{array}$ & MI & $\begin{array}{l}\text { Pressure } \\
\text { overload }\end{array}$ & MI & \\
\hline TSP-1 & Increased & $\begin{array}{l}\text { Increased } \\
\text { during early } \\
\text { phase }\end{array}$ & ND & $\begin{array}{l}\text { Increased inflammatory response; } \\
\text { More extensive postinfarct } \\
\text { remodeling }\end{array}$ & $\begin{array}{l}\text { [Chaulet et al. 2006; Frangogiannis et al. } \\
\text { 2005; Schroen et al. 2004; Wang et al. } \\
\text { 2003] }\end{array}$ \\
\hline TSP-2 & Increased & ND & $\begin{array}{l}\text { Severe cardiac } \\
\text { failure and cardiac } \\
\text { rupture }\end{array}$ & $\begin{array}{l}>90 \% \text { Cardiac rupture within } \\
3 \text { days }\end{array}$ & $\begin{array}{l}\text { [Cleutjens et al. 1999; Schroen et al. } \\
\text { 2004] }\end{array}$ \\
\hline TSP-3 & Increased & ND & ND & ND & [Schroen et al. 2004] \\
\hline TSP-4 & Increased & ND & ND & ND & $\begin{array}{l}\text { [Mustonen et al. 2008; Rÿsa et al. 2005; } \\
\text { Tan et al. 2002] }\end{array}$ \\
\hline
\end{tabular}

10 weeks of age, with approximately $50 \%$ developing quick decompensation at 12-14 weeks of age. Biopsies taken at 10 weeks of age allowed retrospective comparison of gene expression between the decompensated and compensated group. TSP-1, TSP-2, and TSP-3 transcript levels were all significantly enhanced at 10 weeks of age in the rats prone to develop quick decompensation. Moreover, TSP-2 transcript levels were also increased in patients with cardiac hypertrophy, secondary to aortic stenosis, and TSP-2 expression was particularly elevated in patients with a depressed ejection fraction $(<55 \%)$ (Schroen et al. 2004). Other in vivo studies demonstrated enhanced expression of TSP-1 after transverse aortic constriction and sustained

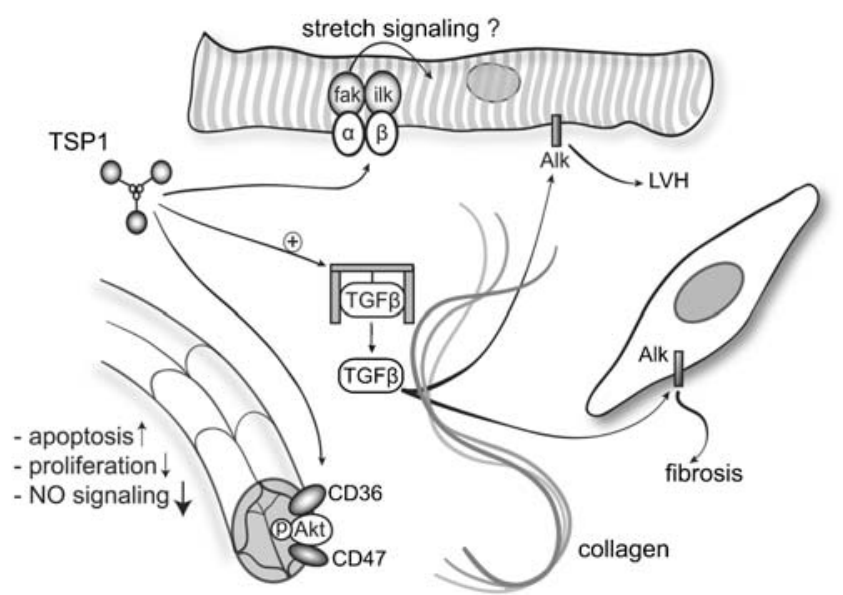

Fig. 1 Potential functions of TSP-1 in cardiac remodeling during pressure overload or after MI. TSP-1 is an inhibitor of angiogenesis and an activator of TGF- $\beta_{1}$, and thereby influences the behavior of endothelial cells, fibroblasts and myocytes. By binding to integrins, TSP-1 might also alter the adhesive or stretch-induced signaling of cells. $\alpha$ indicates $\alpha$-integrin subunit, $\beta$ indicates $\beta$-integrin subunit, fak focal adhesion kinase; ilk integrin-linked kinase; Alk activin-like kinase; $L V H$ left ventricular hypertrophy; $T G F \beta$ transforming growth factor beta alpha-adrenergic drive (Chaulet et al. 2006; D. Wang et al. 2003) (Table 1). A study by Rysä et al. identified the pentameric, B-type TSP-4 to be increased in the hearts of spontaneously hypertensive rats (SHR) in comparison to age-matched Wistar Kyoto rats (WKY) (Rysa et al. 2005) (Table 1). The expression of TSP-4 transcripts gradually increased with age in the SHR, with the highest levels at 20 months of age. TSP-4 expression is also enhanced in response to acute pressure overload induced by angiotensin-II (Ang-II) and arginine-vasopressin (AVP) infusion (Mustonen et al. 2008) (Table 1). Ang-II infusion resulted in a rapid increase in left ventricular (LV) TSP-4 mRNA levels, the highest at $6 \mathrm{~h}$ after infusion. AVP

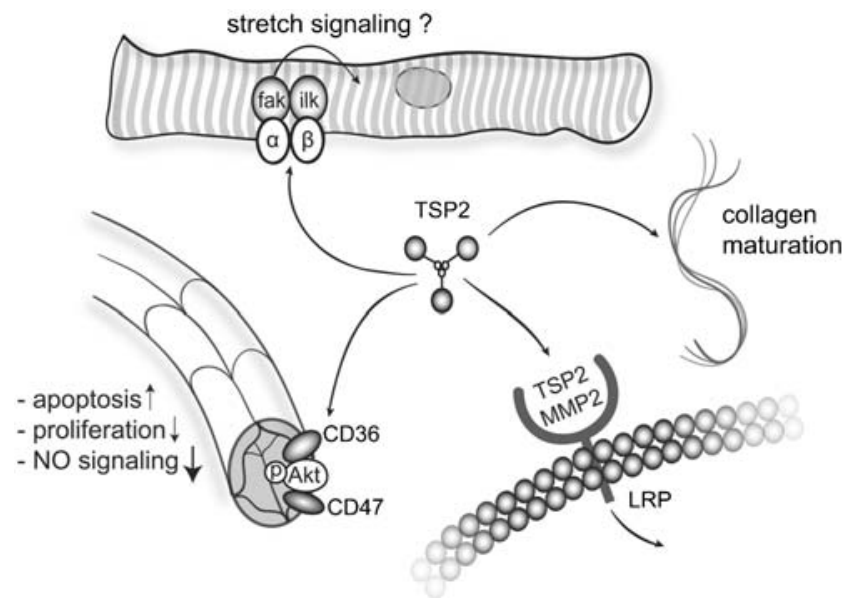

Fig. 2 Potential functions of TSP-2 in cardiac remodeling. Together with TSP-1, TSP-2 is an inhibitor of angiogenesis, and through integrin-binding TSP-2 might also influence adhesive or stretchinduced signaling. An important feature of TSP-2 is its capacity to bind pro- or active MMP-2, resulting in endocytosis via the LRPreceptor, and inhibition of its proteolytic activity. The influence of TSP-2 on collagen maturation has also been established. $\alpha$ indicates $\alpha$-integrin subunit, $\beta$ indicates $\beta$-integrin subunit, fak focal adhesion kinase; ilk integrin-linked kinase; $M M P$ matrix metalloproteinase; $L R P$ low density lipoprotein receptor 
infusion also increased TSP-4 expression, that was limited to LV endothelial cells (Mustonen et al. 2008). Furthermore, TSP-4 was upregulated at an early stage in response to cardiac overload, similar to TSP-1 (Mustonen et al. 2008). TSP-4 expression also increased significantly in patients with end-stage dilated cardiomyopathy (Tan et al. 2002) (Table 1). These studies indicate an important role for TSP$1,-2,-3$, and -4 in left ventricular hypertrophic cardiac remodeling following pressure overload.

ECM remodeling during cardiac hypertrophy: thrombospondins and the MMP-TIMP balance

Matrix metalloproteinases (MMPs) and tissue inhibitor of metalloproteinases (TIMPs) are actively involved in the process of hypertrophic cardiac remodeling (Spinale 2007). MMPs degrade ECM proteins and are divided into four classes:(1) collagenases, which include MMP-1, -8, -13, and -18; (2) the gelatinases, which include MMP-2, and -9; (3) the stromelysins, including MMP-3, -10, and -11; and (4) the membrane-type MMPs (MT-MMPs), including MMP-14, -17, -24, and -25. The TIMP family consists of 4 family members: TIMP1-4. In the uninjured heart, a balance between the synthesis and breakdown of ECM is maintained by MMPs and TIMPs (Spinale 2007). During the transition of cardiac hypertrophy to heart failure, however, the balance shifts towards increased MMP activity, leading to myocyte slippage and ventricular dilatation.

TSP-1 and TSP-2 share a large overall similarity in their protein structure and therefore interact with the same ligands. Both TSP-1 and TSP-2 contain three different repeated sequence motifs (TSRs), known as type 1, type 2 , and type 3 repeats. These TSRs allow TSP-1 and TSP2 to interact with MMPs, thereby regulating the activity of these proteinases (Emonard et al. 2004; Yang et al. 2000). TSP-2-null skin fibroblasts have a defect in attachment to different matricellular proteins in vitro as a consequence of increased levels of active MMP-2 (Yang et al. 2000). In addition, the increased activity of MMP-2 causes enhanced proteolysis of cell-surface tissue transglutaminase (tTG), an enzyme important for collagen cross-linking (Agah et al. 2005). Later, it was demonstrated that TSP-2 is actively involved in the clearance of MMP-2 by directly targeting MMP-2 to form a complex that is endocytosed by the low density lipoprotein-related scavenger receptor (LRP1) (Yang et al. 2001) (Fig. 2). In a model of dermal wound healing, mice that lack TSP-2 showed aberrant ECM remodeling associated with increased levels of MMP-2, MMP-9, TIMP-1 and TIMP-2 (Maclauchlan et al. 2009). In concordance, TSP-2-null mice had increased MMP-2 activity after infusion of angiotensin II, contributing to an increased incidence of left ventricular rupture and dilatation (Schroen et al. 2004).
Whether TSP-1 may also regulate MMP activity is less certain, depending on cell-type specific actions of TSP-1. It increases MMP-9 activity in endothelial cells and in gastric cancer (Albo et al. 2002; Qian et al. 1997), whereas others reported an inhibition of tumor growth by TSP-1 via its attenuation of MMP-9 activity (Rodriguez-Manzaneque et al. 2001). In vascular smooth muscle cells, TSP-1 induced MMP-2 activity (Lee et al. 2003), but the mechanism remains unclear. The contradictory results of TSP-1 on the regulation of MMP activation may depend on the opposite effects exerted by the different domains of TSP-1. Taraboletti et al. reported that, in rabbit corneal endothelial cells, the $25-\mathrm{kDa}$ heparin-binding domain of TSP-1 increased MMP-2 and MMP-9 activity and decreased TIMP-2 levels, whereas the $140 \mathrm{kDa}$ carboxy-terminal fragment of TSP-1 upregulated TIMP-2 expression and inhibited MMP-2 and MMP-9 activities (Taraboletti et al. 2000). Similar experiments with capillary endothelial cells isolated from bovine hearts confirmed these results (Donnini et al. 2004). Reports on the influence of TSP-3, TSP-4, and TSP-5 on MMP activity are lacking.

Thrombospondins and the renin-angiotensin system (RAS) in cardiac hypertrophy

The RAS is activated in response to pressure overload of the heart, and contributes to the process of myocardial remodeling (Heineke and Molkentin 2006; Rosenkranz 2004). The effector molecule of the RAS, angiotensin-II (Ang-II), triggers cell-specific responses in cardiac fibroblasts and myocytes through binding to the angiotensin type I receptor $\left(\mathrm{AT}_{1} \mathrm{R}\right)$ (Crabos et al. 1994; Miyata and Haneda 1994; Schorb et al. 1993; Villarreal et al. 1993). Binding of Ang-II to the $\mathrm{AT}_{1} \mathrm{R}$ induces synthesis of the locally secreted growth factor transforming growth factor $\beta_{1}$ (TGF- $\left.\beta_{1}\right)$ in cardiac fibroblasts and myocytes. Interaction of TGF- $\beta_{1}$ with its receptor causes expression of ECM proteins, collagen synthesis, and proliferation of cardiac fibroblasts (Eghbali et al. 1991; Heimer et al. 1995; Sappino et al. 1990; Tomasek et al. 2002; Villarreal et al. 1996). Tissue culture experiments showed that the paracrine release of TGF- $\beta_{1}$ from fibroblasts mediates Ang-II induced hypertrophy of cardiac myocytes as blocking antibodies to TGF- $\beta_{1}$ abolished myocyte growth (Gray et al. 1998). Also, blockade of the $\mathrm{AT}_{1} \mathrm{R}$ inhibits the expression of TGF- $\beta_{1}$ as well as the resulting cardiac hypertrophy and fibrosis, indicating a crucial link between Ang-II and TGF- $\beta_{1}$ (Tokuda et al. 2004; Tomita et al. 1998). Further support for the link between the RAS and TGF- $\beta_{1}$ is provided by studies that show upregulation of TGF- $\beta_{1}$ in patients with idiopathic hypertrophic cardiomyopathy and dilated cardiomyopathy (Casscells et al. 1990; Hao et al. 1999; Takahashi et al. 1994; Thompson et al. 
1988; Tomita et al. 1998; Villarreal and Dillmann 1992; Wunsch et al. 1991), and upregulation of angiotensin converting enzyme (ACE) and TGF- $\beta_{1}$ in pressureoverloaded human hearts is correlated with the degree of fibrosis (Hein et al. 2003).

From the sequence similarity between TSP-1 and TSP-2, it could be expected that the binding partners of TSP-1 also interact with TSP-2. The type I repeats, which are characteristic for both TSP-1 and TSP-2, have been described in the activation of latent TGF- $\beta_{1}$ by TSP-1 (Schultz-Cherry et al. 1995). The activation of TGF- $\beta_{1}$ links TSP-1 to the process of hypertrophic cardiac remodeling (Fig. 1). As indicated above, TSP-1 is increased in cardiac hypertrophy. Activation of latent TGF- $\beta_{1}$ involves direct interaction with two sequences in the type 1 repeats of TSP-1. The KRFK sequence in the first TSR activates latent TGF- $\beta_{1}$, whereas the GGWSHW sequence binds active TGF- $\beta_{1}$ and potentially orients the TSP molecule (Schultz-Cherry et al. 1995). TSP-2 lacks the KRFK sequence in the TSR, but contains the GGWSHW motif, and therefore can bind, but not activate TGF- $\beta_{1}$. The significance of TSP-1-mediated TGF- $\beta_{1}$ activation is supported by studies in vivo. Histological abnormalities, e.g., leukocyte infiltration and inflammatory changes in the lung and pancreas, are strikingly similar in young TSP-1null mice and TGF- $\beta_{1}$-null mice (Crawford et al. 1998). Moreover, these abnormalities could be partially reversed by treatment of TSP-1-null mice with KRFK, a TSP-1derived peptide that binds the KRFK motif and activates TGF- $\beta_{1}$. The synthetic peptide GGWSHW, based on a sequence in the TSR of TSP-1 and TSP-2, inhibited activation of TGF- $\beta_{1}$ by TSP- 1 . In addition, TSP- 2 inhibits activation of latent TGF- $\beta_{1}$ by TSP-1, presumably via competitive binding to TGF- $\beta_{1}$ when both TSPs are present (Schultz-Cherry et al. 1995). Whether this possibility is the case in remodeling tissues is questionable, since the expression of TSP-1 and TSP-2 is differentially controlled (Bornstein et al. 2004). Recently, the importance of TSP-1mediated TGF- $\beta_{1}$ activation during cardiac remodeling has been shown, as a peptide antagonist of TSP-1-dependent TGF- $\beta_{1}$ activation prevented fibrosis and improved cardiac function (Belmadani et al. 2007). Analyses of active TGF- $\beta_{1}$ levels in TSP-2-null mice during LVH would provide an insight in the role of TSP-1 and TSP-2 expression in controlling TGF- $\beta_{1}$ activation during LVH remodeling.

Thrombospondin-integrin interaction in cardiac hypertrophy

Integrins and CD47/IAP are cell surface receptors that are important in physiological cell functioning by mediating interactions between cells and their ECM. In addition to their structural role in the anchoring of cells, integrins participate in signal transduction from the "outside to inside" and "inside to outside" of the cell (Lal et al. 2009). Therefore, integrin and CD47/IAP signaling plays a crucial role in controlling cell behavior in response to various stimuli, via regulation of processes such as cell adhesion, migration, proliferation, survival and apoptosis (Isenberg et al. 2008b; Lal et al. 2009). In the heart, integrins are involved in normal cardiac mechanotransduction, and have been shown to be indispensible during cardiac remodeling (Shai et al. 2002). Focal adhesion kinase (FAK) and integrin-linked kinase (ILK) are downstream targets of integrin signaling and are implicated in cardiac remodeling (Lal et al. 2009). FAKnull mice developed dilated cardiomyopathy in response to pressure overload due to the lack of a proper hypertrophic response (DiMichele et al. 2006). Zebrafish with a mutation in the ILK-gene and ILK-null mice both display spontaneous cardiac failure (Bendig et al. 2006; White et al. 2006), and ILK expression has been associated with the development of cardiac hypertrophy (Lu et al. 2006).

Together these studies emphasize that interactions with integrins and subsequent activation of its downstream targets are involved in cardiac failure. Several studies have identified TSPs as ligands for integrins and CD47/IAP. The RGD-containing type-3 repeat of TSP-1 was reported to interact with $\alpha \mathrm{v} \beta 3$ integrin in human endothelial cells to mediate cell adhesion in vitro (Staniszewska et al. 2007). Four $\beta 1$ integrin binding sites have been mapped to the N-terminus of TSP-1. The $\alpha 3 \beta 1$ integrin recognizes a NVR motif and stimulated angiogenesis and endothelial cell behavior (Chandrasekaran et al. 2000; Krutzsch et al. 1999). A second integrin, $\alpha 4 \beta 1$, was mapped to the LDVP sequence in TSP-1 that was also conserved in TSP-2. Interaction of TSP-1 with $\alpha 4 \beta 1$ on vascular endothelial cells regulates angiogenesis in vivo and affects cell proliferation, adhesion, and migration in vitro (Calzada et al. 2004). Like $\alpha 4 \beta 1$, the binding site for $\alpha 6 \beta 1$ was conserved in both TSP-1 and TSP-2 and was reported to mediate adhesion and chemotaxis of microvascular endothelial cells (Calzada et al. 2003). Recently, a fourth integrin, $\alpha 9 \beta 1$, was recognized as a receptor for TSP-1 that induces endothelial cell proliferation and migration and thereby modulates angiogenesis (Staniszewska et al. 2007). In vascular smooth muscle cells (VSMC), TSP-1 can induce FAK phosphorylation, which is essential for migration (Gahtan et al. 1999; X. J. Wang et al. 2008). In addition, Gao et al. showed that TSP-1 also binds to CD47/IAP that in turn associates with $\alpha \mathrm{v} \beta 3$ and leads to cell spreading, an activity that was correlated with increased FAK phosphorylation (Gao et al. 1996). These studies clearly demonstrate a role for TSPs in the modulation of 
integrin signaling, particularly in endothelial cells and VSMC during vascular remodeling. Although TSPs are recognized as binding partners of integrins and CD47/IAP and can activate FAK, no direct evidence for a role of TSPs in the stretch-sensing machinery is available. Therefore, their importance in the integrin-mediated hypertrophic response remains to be elucidated.

Thrombospondins and angiogenesis in cardiac hypertrophy

TSP-1 and TSP-2 are recognized as potent inhibitors of angiogenesis [reviewed in (Armstrong and Bornstein 2003) and see review by Bornstein in this issue]. TSPs exert their anti-angiogenic effects through several mechanisms: inhibition of endothelial cell-cycle progression, prevention of endothelial cell mobilization, and/or induction of endothelial cell apoptosis (Armstrong et al. 2002; RodriguezManzaneque et al. 2001; Simantov and Silverstein 2003) (Figs. 1 and 2). In addition, TSP-2 influences angiogenesis through modulation of MMP activity (Krady et al. 2008). Pathological hypertrophy is associated with a reduced capillary density, as found in several human cardiac diseases (Hudlicka et al. 1992; Karch et al. 2005). NO and Akt signaling are important in the process of angiogenesis and have been implicated in physiological and pathological cardiac function (Rastaldo et al. 2007).

First recognized as an endothelial-derived relaxing factor (Ignarro et al. 1987), NO is produced through conversion of L-arginine to L-citrulline by three NO synthases (nNOS, eNOS, and iNOS) (Isenberg et al. 2008a). In the heart, NO limits cardiac remodeling after MI and participates in the control of heart rate and contractility (Rastaldo et al. 2007). In comparison with WT explants, TSP-1-null tissue explants show an enhanced angiogenic response elicited by NO (Isenberg et al. 2005). NO induced endothelial cell proliferation, associated with a decrease in TSP-1 levels that was dependent on phosphorylation of ERK, whereas exogenous TSP-1 can suppress NO mediated ERK phosphorylation, data indicating a feedback loop between TSP-1 and NO (Ridnour et al. 2005). NO stimulates endothelial cell motility and adhesion to type I collagen in a cGMPdependent manner. Picomolar concentrations of exogenous TSP-1 potently block NO-mediated stimulation of cGMP (Isenberg et al. 2005). In addition, recombinant type-1 repeats of TSP-1 and a CD36 agonist antibody have a similar effect, whereas the N-terminal domain of TSP-1 did not inhibit NO-mediated stimulation of cGMP. These results indicate that the inhibitory effects of TSP-1 on pro-angiogenic NO signaling are mediated through binding to CD36. Later, it was reported that TSP-1 inhibits NO stimulated responses in vascular smooth muscle cells in an identical manner as previously described in endothelial cells (Isenberg et al. 2006b). A study in CD47/IAP-null cells demonstrated that, whereas ligation of CD36 is sufficient to block NO-mediated responses in VSMC and endothelial cells, only CD47/IAP is crucial for TSP-1 to exert its inhibitory effects (Isenberg et al. 2006a). TSP-2 shares the $\mathrm{C}$-terminal binding motif for CD47/IAP with TSP-1, and both TSPs have been found to regulate inflammatory responses through this receptor (Lamy et al. 2007). However, TSP-2 binds less avidly to CD47/IAPexpressing cells compared to TSP-1. Consistent with these findings TSP-2 inhibits NO-mediated cGMP synthesis in vascular cells less efficiently (Isenberg et al. 2009a).

Short-term and long-term Akt activation have different effects on cardiac hypertrophy and angiogenesis (Shiojima et al. 2005). Short-term activation of Akt in transgenic mice results in physiological hypertrophy and concomitant enhanced angiogenesis, responses resulting in maintenance of vascular density (Shiojima et al. 2005). This capillary growth is mediated by increased expression of VEGF and angiopoietin-2 (Ang-2) after short-term Akt activation, which is dependent on mTOR (Shiojima et al. 2005). Long-term activation of Akt, on the other hand, results in down regulation of VEGF and Ang-2, possibly due to decreased expression of mTOR, and is accompanied by a decrease in capillary density. Akt-null mice displayed enhanced angiogenic responses and an ECM reduced in density, which may facilitate growth of new capillaries in the skin of Akt-null mice (Chen et al. 2005). Importantly, the observed abnormalities in collagen organization, enhanced angiogenesis, and vascular leakage, closely resemble the phenotype of mice lacking TSP-1 and TSP-2 (Chen et al. 2005). TSP-1 and TSP- 2 are decreased in the tissues of Akt-null mice, and the increased angiogenesis found in these animals could be normalized by re-expression of TSP-1 and TSP-2 (Chen et al. 2005). Thus, the overall effect of Akt on angiogenesis is suppressive and involves controlling the expression of angiostatic TSP-1 and TSP-2. Recently, the link between TSPs and Akt in angiogenesis was confirmed by a study demonstrating that TSP-1 modulates microvascular remodeling in the retina by antagonizing Akt-signaling triggered by VEGF, whereas no significant effects of TSP-2 were reported (Simantov et al. 2005; Sun et al. 2009). Whether or not inhibition of VEGF-induced Akt-signaling by TSP-1 depends on direct blockade of VEGF signaling, or sequestration of Aktsignaling, remains uncertain. Interestingly, recent evidence revealed increased basal VEGF levels in TSP-1-null mice, associated with increased capillary density in cardiac and skeletal muscle. These data indicate that TSP-1 regulates angiogenesis via a direct effect on VEGF (Malek and Olfert $\mathrm{Ph}$ 2009). Whether the upregulation of TSPs during cardiac hypertrophy is important for the balance between myocyte and capillary growth, via modulation of NO- and/or Aktsignaling, remains to be investigated. 


\section{Thrombospondins in cardiac remodeling after acute myocardial infarction}

MI is one of the major risk factors in the development of heart failure, and accounts for $62 \%$ of all cases (Bansal et al. 2006). During MI, part of the heart is subjected to an abrupt lack of perfusion that leads to rapid death of the cardiac myocytes and the formation of a scar. Grossly, infarct healing consists of three overlapping phases; the inflammatory phase, the proliferative phase, and the maturation phase (Frangogiannis 2006). The inflammatory phase takes place within hours after the onset of MI and is marked by the influx of leukocytes that remove the dead myocytes, followed by the influx of other inflammatory cells. Two to 3 days after MI, the onset of the proliferative phase of infarct healing begins with the formation of granulation tissue, which is rich in inflammatory cells and myofibroblasts that are capable of producing large amounts of ECM proteins. In parallel with the proliferation phase of infarct healing, new blood vessels start to appear in the infarcted area. Finally, after 2-3 weeks, the cell-rich granulation tissue evolves into a mature, collagen-based scar, characterized by the disappearance of cells and by the cross-linking of secreted collagen. During all phases of infarct healing, the composition of the ECM plays a crucial role in regulating cell behavior by modulation of cell phenotype and gene expression (Dobaczewski et al. 2006). The following paragraphs discuss the expression and function of TSPs during the three phases of wound healing after MI. We discuss only TSP-1 and TSP-2 because they are known to play a role in infarct healing.

\section{Expression of TSPs after acute myocardial infarction}

The expression of TSP-1 precedes that of TSP-2 and partially overlaps it during the process of wound healing. This important feature could explain some of the phenotypes found in the respective null mice, as described below (Table 1). TSP-1 is secreted by inflammatory cells, and its expression is high during early phases of wound healing, whereas TSP-2 is secreted mostly by fibroblasts, and is therefore expressed at high levels during later stages of wound healing (Agah et al. 2002; Bornstein et al. 2004).

Thrombospondins and the inflammatory response

A role of TSP-1 and TSP-2 in wound repair is suggested by their dynamic expression pattern during the different phases of wound healing. TSP-1 is secreted by inflammatory cells during the acute phase of tissue repair, whereas its expression drops during the proliferative phase of healing (Agah et al. 2002). The role of TSP-1 in the inflammatory phase after MI has been described by Frangogiannis et al., who discovered that TSP-1 prevents expansion of healing myocardial infarcts (Frangogiannis et al. 2005) (Table 1). First, TSP-1 expression was enhanced in a canine ischemiareperfusion model. Thereafter, they extended this model to TSP-1-null and WT mice. In infarcted WT mice TSP-1 protein was noted after $24 \mathrm{~h}$ to 7 days, and expression was localized to the border zone of the infarct (Frangogiannis et al. 2005). TSP-1-null mice displayed higher levels of chemokine and cytokine transcripts in healing infarcts, which were associated with increased and prolonged abundance of macrophages and myofibroblasts in the infarct zone, as well as in remote, non-infarcted myocardium. This observation indicates that TSP-1-null mice have an increased inflammatory response after ischemiareperfusion, which correlates with the enhanced ventricular dilation after $\mathrm{MI}$ in these animals. The mechanism responsible for mediating the inflammatory response by TSP-1 after MI is likely to involve the activation of local TGF- $\beta_{1}$. As previously discussed, TSP- 1 is a major activator of TGF- $\beta_{1}$ in vivo (Crawford et al. 1998). In non-infarcted murine hearts TSP-1 is not expressed, and levels of chemokine and cytokine transcripts are similar between WT and TSP-1-null animals. However, infarcted hearts show a strong inflammatory response with marked upregulation of TGF- $\beta_{1}$ (Dewald et al. 2004). In addition, infarcted hearts of TSP-1- null mice showed a trend towards decreased phosphorylation of the intracellular effector of TGF- $\beta_{1}$, Smad2. Alternatively, the angiostatic effects of TSP-1 may regulate infarct healing. However, no differences in microvascular profiles between WT and TSP1- null mice were reported after MI (Frangogiannis et al. 2005). Therefore, the selective expression of TSP-1 in the infarct border zone is suggested to function as a barrier that locally suppresses inflammatory chemokines and cytokines through its TGF- $\beta_{1}$-activating effects, and prevents extension of the inflammatory process into the non-infarcted area.

In contrast to TSP-1, the structurally similar TSP-2 does not activate latent TGF- $\beta_{1}$ and is therefore likely to affect the inflammatory process through other mechanisms. Different studies concerning the role of TSP-2 in the inflammatory response reported contradictory results. In oxazolone-induced inflammation of the skin, lack of TSP-2 results in an enhanced inflammatory response. TSP-2-null mice exhibited increased angiogenesis, edema, and inflammatory infiltration (Lange-Asschenfeldt et al. 2002). Moreover, microvascular leakage was enhanced in the inflamed skin of TSP-2-null mice, a result indicating that TSP-2 controls vascular permeability during inflammation. Another study showed similar phenotypes in CD47/IAP-, TSP-1-, and TSP-2-null mice after oxazolone-induced inflammation. The authors suggested that the observed prolonged inflammation resulted from a deficiency in T-cell 
apoptosis in these mice that was associated with a defect in TSP-CD47/IAP interactions (Lamy et al. 2007). In contrast to oxazolone-induced inflammation, the early phase of dermal skin wound healing (0-4 days) did not differ between WT and TSP-2-null mice, and there were no signs of increased inflammatory infiltration. However, 7 days after wounding, progressive and significant differences were revealed between WT and TSP-2-null mice, the latter showing accelerated healing with irregular granulation tissue, and increased angiogenesis (Bornstein et al. 2004; Kyriakides et al. 1999). Therefore, one might speculate that TSP-2 affects the inflammatory response at a later phase of wound healing, in comparison with TSP-1, presumably via regulation of vascular permeability and T-cell apoptosis during inflammation. With respect to the role of TSP-2 in MI, a high incidence of cardiac rupture in TSP-2-null mice within 3 days after acute MI was reported (Cleutjens et al. 1999). The inflammatory response in the hearts of these TSP-2-null mice has not been evaluated. These findings imply an important role for TSP-2 in controlling the structural integrity during ECM remodeling in the heart.

Thrombospondins and the proliferative phase of infarct healing

After the phase of acute inflammation, 2 to 3 days after MI, granulation tissue begins to form in the border zone of the infarct. Key features of this granulation tissue are the abundance of inflammatory cells, myofibroblasts and small blood vessels. Both TSP-1 and TSP-2 are potent inhibitors of angiogenesis and exert their angiostatic effects via interaction with CD36 and/or CD47/IAP (Isenberg et al. 2005; Simantov and Silverstein 2003) (Figs. 1 and 2). TSP$1 \mathrm{mRNA}$ is markedly induced $6-24 \mathrm{~h}$ after reperfusion, and TSP-1 immunoreactivity showed specific localization in the infarct border zone 7 to 28 days after MI. In addition, the vascular network in TSP-1-null infarcts was comparable to neovascularization in WT mice (Frangogiannis et al. 2005). Consistent with these findings, angiogenesis has not been found to be increased in skin wounds of mice lacking TSP1 (Agah et al. 2002). A plausible explanation for this observation is that TSP-1 is not expressed during the late proliferative phase and during remodeling, when neovascularization occurs. TSP-1 is a major activator of latent TGF$\beta_{1}$, an important factor in myofibroblast differentiation. Surprisingly, TSP-1-null infarcts contained higher numbers of myofibroblasts (Frangogiannis et al. 2005). These data indicate that TSP-1 is more involved in controlling the inflammatory response and preventing expansion of the granulation tissue into the non-infarcted area, rather than affecting angiogenesis, during this phase of wound healing.

The effects of TSP-2 on angiogenesis during the proliferative phase after MI cannot be studied directly, due to the early cardiac ruptures that occur in TSP-2-null animals after acute MI (Cleutjens et al. 1999). However, during cutaneous wound healing TSP-2 exhibits a time/ phase dependent expression pattern. In early wounds, when there is increased angiogenesis, TSP-2 is sparse and can be localized to a small number of fibroblasts. Levels of TSP-2 become high, and its expression widespread, during late stages of healing, which coincide with ECM remodeling and vascular regression (Kyriakides et al. 1999). In contrast to TSP-1-null mice, TSP-2-null mice exhibited increased vascular density after dermal wound healing together with the presence of an abnormal, loosely organized collagen matrix (Bornstein et al. 2004; Kyriakides et al. 1999). These findings are consistent with the phenotypes of TSP-1 and TSP-2-null mice that show alterations in the early and late phases of wound healing, respectively. TSP-2 is likely to be important for controlling angiogenesis and the integrity of the newly formed matrix during later phases of infarct healing (Fig. 2).

Thrombospondins and maturation of the infarct scar

Maturation of the infarct scar is characterized by removal of inflammatory cells, regression of blood vessels, and crosslinking of the deposited collagen (Blankesteijn et al. 2001). Since the levels of TSP-1 are low during late stages of wound healing, the protein was expected to play a minor role during infarct maturation. After ischemia-reperfusion, TSP-1 was observed up to 28 days after injury; however, its expression was highly selective for the infarct border zone, and was minimal in the infarct center. These data support the hypothesis that TSP-1 is not critical for infarct scar maturation (Frangogiannis et al. 2005). However, TSP-1 could affect maturation of the infarct scar through the activities of TGF- $\beta_{1}$, as TGF- $\beta_{1}$ is known to promote fibrosis via enhanced collagen deposition (Lijnen et al. 2000) (Fig. 1). Furthermore, TGF- $\beta_{1}$ inhibits MMP activities and increases synthesis of proteinase inhibitors such as plasminogen activator inhibitor (PAI) and TIMPs (Schiller et al. 2004). Consistent with these functions, enhanced MMP-9 activity was reported in the infarct border zone in the absence of TSP-1, which in turn could explain the enhanced ventricular dilation after MI in TSP-1-null mice. Whether TSP-1 is of significant importance during this phase of late infarct healing remains to be determined.

In contrast to TSP-1, TSP-2 is expressed during the phase of scar maturation, and TSP-2-null mice show abnormalities in collagen fibril formation. TSP-2 might therefore be an important regulator of infarct scar formation (Kyriakides et al. 1998). By scanning electron microscopy, abnormal loop-like fibers of large diameter were detected in the dermis of TSP-2-null mice. In addition, transmission electron microscopy showed that collagen fibrils in the 
dermis of TSP-2-null mice were wider in diameter, in comparison to WT fibrils (Kyriakides et al. 1998). The abnormally organized collagen matrix might be caused by increased levels of MMP-2 and MMP-9 in wounds of TSP2-null mice (Bornstein et al. 2004). The relevance of modulation of MMP activities by TSP-2 was supported by the observation that peak levels of MMP-2 and MMP-9 in the wounds of TSP-2-null mice coincide with the highest content of TSP-2 in WT wounds. Together these studies indicate that TSP-2 is a crucial regulator of the integrity of the cardiac ECM during maturation of the infarct scar, presumably via regulation of MMP activity, and subsequent deposition of a cross-linked collagen matrix (Fig. 2).

Thrombospondin polymorphisms and myocardial infarction

The importance of TSPs in infarct healing has been established in the above-described mouse models of acute MI. However, it is important to know whether TSPs are also involved in human cardiac diseases. This paragraph describes their potential role in the progression of atherosclerosis, plaque rupture and platelet biology, thereby linking TSP gene alterations to the risk of MI.

Topol et al. were the first to describe a link between single nucleotide polymorphisms (SNPs) in TSP genes and MI (Topol et al. 2001). The SNPs affected the amino acid sequences of TSP-1 (Asn700Ser, 2210A/G) and TSP-4 (Ala387Pro, 1186G/C), whereas for TSP-2 a SNP was found in the 3' untranslated region (UTR) (3949T/G). The SNP in TSP-1 lowers its capacity for calcium binding, an alteration that could influence the structure and function of this matricellular protein. In platelets, the TSP-1 SNP is associated with increased cell-surface expression of TSP-1 and enhanced platelet aggregation. These results provide a mechanism for the increased risk of MI in individuals bearing the TSP-1 SNP. The TSP-4 387Pro variant is dominant, and exhibits increased calcium binding, relative to WT TSP-4, although the expression and processing of TSP-4 are not affected in cells with this SNP. The TSP-4 SNP alters endothelial cell behavior by its interference with adhesion and proliferation. Blocking endothelial cell repair, increasing smooth muscle cell proliferation, and augmenting neutrophil activation by the TSP-4 387Pro variant could result in atherosclerotic lesions and an increased risk of MI. The SNP found in the 3' UTR of TSP-2 mRNA results in a different secondary structure, as predicted by the M-fold model, which might affect protein expression. Consistent with this possibility, the expression of a luciferase reporter with the TSP-2 3949G variant was substantially lower in human umbilical vein endothelial cells, in comparison to that of the TSP-2 3949T variant. These data suggest decreased expression of TSP-2 in the vascular wall of individuals with the 3949G SNP.
However, the association between TSP SNPs and MI is not a consistent finding. Koch et al. determined the genotypes related to the SNPs in the genes for TSP-1, TSP-2, and TSP-4 in a large, case-control sample of MI and performed a meta-analysis of data from their own and from previous studies (Koch et al. 2008). They described mildly, but significantly, elevated risks of $\mathrm{MI}$ in individuals carrying the TSP-2 3949G SNP, whereas no correlation was found for the TSP-1 and TSP-4 SNP variant with MI. Their meta-analysis of available data revealed that none of the polymorphisms was linked with the risk of MI.

Because studies with TSP-null mice indicate a role for TSP-1 and TSP-2 in infarct healing, it would be tempting to investigate the influence of TSP SNPs on infarct healing and the transition toward heart failure. These studies would provide evidence confirming the importance of TSPs in cardiac remodeling after acute MI.

\section{Thrombospondins as key players during cardiac remodeling}

In the complex process of cardiac remodeling, many growth factors, cytokines, and other proteins have been recognized as key players. Lately, non-structural proteins residing in the ECM, such as certain matricellular proteins including periostin, were highlighted as important factors influencing cardiac remodeling. In this review, we have discussed the functions and possible actions of the matricellular TSPs during cardiac remodeling (Figs. 1 and 2).

First, evidence supporting the notion that TSPs are involved in cardiac remodeling was provided by different studies that reported upregulation of different TSPs after cardiac injury. Several groups reported elevated expression of TSP-1, TSP-2, TSP-3 and TSP-4 in different models of pressure overload (Table 1). Schroen et al. identified TSP-2 as an important regulator of the transition from compensated LVH towards heart failure (Schroen et al. 2004). TSP-2-null mice, after Ang-II infusion, showed advanced myocardial rupture accompanied by increased levels of MMP-2. MMPs and TIMPs are actively involved in hypertrophic cardiac remodeling. TSP-1 and TSP-2 contain TSR motifs that are able to interact with MMPs to regulate their activity. Therefore, TSPs are likely to play a role in the process of LVH by controlling the MMP-TIMP balance and thereby regulating breakdown of the ECM. A second mechanism by which TSPs could affect LVH depends on the regulation of the activity of the pro-fibrotic, antiinflammatory factor, TGF- $\beta_{1}$, which is synthesized after induction of the RAS and contributes to myocardial remodeling. TSP-1 binds TGF- $\beta_{1}$ via its GGWSHW motif and can subsequently activate the protein through its KRFK motif. 
The complex domain structure of TSP-1 and TSP-2 allows them to interact with a large number of cell surface receptors, including integrins and CD47/IAP, that participate in signal transduction. TSPs could affect the development of LVH as regulators of angiogenesis via interactions with integrins, CD36 and CD47/IAP or as targets of chronic Akt activation and inhibitors of NO signaling.

Studies that investigated TSPs after MI suggested that TSP-1 and TSP-2 have distinct functions depending on their spatiotemporal expression. Models of wound healing in mice revealed that TSP-1 is markedly induced during the acute inflammatory phase and drops during later phases of healing, whereas TSP-2 expression is limited to a small number of fibroblasts during inflammation and peaks in the proliferative phase and during scar maturation. In a setting of MI, TSP-1-null infarcts revealed more inflammation and expansion of the infarct, whereas no differences in vascularization were reported. These data indicate that TSP-1 functions to control the inflammatory response and prevent infarct expansion, most likely via regulation of TGF- $\beta_{1}$ activity during the first stage of infarct healing. That TSP-2-null mice display pronounced cardiac rupture after MI, indicates a crucial role for TSP-2 in regulation of the integrity of the cardiac ECM during remodeling, presumably through regulation of the activities of MMP-2 and MMP-9.

We speculate that TSPs are crucial mediators of cardiac remodeling through their influence on various processes, due to their spatiotemporal expression pattern and structure. TSPs might directly influence cardiomyocyte function through interaction with various surface receptors such as integrins, CD47/IAP, and CD36, whereas they can regulate ECM remodeling through their effect on MMP activation. Also, their effects on inflammation and angiogenesis might be important during cardiac remodeling. Thus, we postulate that the TSPs are important in a variety of cardiac diseases, as TSPs can modulate cell behavior through interactions with different surface receptors, with their specific effects depending on the cell type and the nature of the remodeling process.

Studies addressing the role of TSPs in remodeling after cardiac injury are limited. However, in this review we present strong evidence that TSPs are key players during hypertrophic and ischemic cardiac remodeling. Increasing our understanding of these proteins affords new opportunities for intervention to prevent the transition towards heart failure in patients suffering from cardiac diseases.

Acknowledgments This study was supported by research grants of the Netherlands Heart Foundation (NHS 2005B082, NHS 2007B036, 2008B011), and a VIDI grant of the Dutch Research Foudation to SH.

Conflict of Interest There are no conflicts of interest.
Open Access This article is distributed under the terms of the Creative Commons Attribution Noncommercial License which permits any noncommercial use, distribution, and reproduction in any medium, provided the original author(s) and source are credited.

\section{References}

Agah A, Kyriakides TR, Lawler J, Bornstein P (2002) The lack of thrombospondin-1 (TSP1) dictates the course of wound healing in double-TSP1/TSP2-null mice. Am J Pathol 161(3):831-839

Agah A, Kyriakides TR, Bornstein P (2005) Proteolysis of cellsurface tissue transglutaminase by matrix metalloproteinase-2 contributes to the adhesive defect and matrix abnormalities in thrombospondin-2-null fibroblasts and mice. Am J Pathol 167 (1):81-88

Albo D, Shinohara T, Tuszynski GP (2002) Up-regulation of matrix metalloproteinase 9 by thrombospondin 1 in gastric cancer. $\mathrm{J}$ Surg Res 108(1):51-60

Armstrong LC, Bornstein P (2003) Thrombospondins 1 and 2 function as inhibitors of angiogenesis. Matrix Biol 22(1):63-71

Armstrong LC, Bjorkblom B, Hankenson KD, Siadak AW, Stiles CE, Bornstein P (2002) Thrombospondin 2 inhibits microvascular endothelial cell proliferation by a caspase-independent mechanism. Mol Biol Cell 13(6):1893-1905

Bansal D, Chahoud G, Smith ES, Mehta JL (2006) Prevention of heart failure. Curr Opin Cardiol 21(5):510-516

Belmadani S, Bernal J, Wei CC, Pallero MA, Dell'italia L, MurphyUllrich JE, Berecek KH (2007) A thrombospondin-1 antagonist of transforming growth factor-beta activation blocks cardiomyopathy in rats with diabetes and elevated angiotensin II. Am J Pathol 171(3):777-789

Bendig G, Grimmler M, Huttner IG, Wessels G, Dahme T, Just S, Trano N, Katus HA, Fishman MC, Rottbauer W (2006) Integrinlinked kinase, a novel component of the cardiac mechanical stretch sensor, controls contractility in the zebrafish heart. Genes Dev 20(17):2361-2372

Blankesteijn WM, Creemers E, Lutgens E, Cleutjens JP, Daemen MJ, Smits JF (2001) Dynamics of cardiac wound healing following myocardial infarction: observations in genetically altered mice. Acta Physiol Scand 173(1):75-82

Bornstein P, Agah A, Kyriakides TR (2004) The role of thrombospondins 1 and 2 in the regulation of cell-matrix interactions, collagen fibril formation, and the response to injury. Int $\mathrm{J}$ Biochem Cell Biol 36(6):1115-1125

Braunwald E (1997) Shattuck lecture - cardiovascular medicine at the turn of the millennium: triumphs, concerns, and opportunities. $\mathrm{N}$ Engl J Med 337(19):1360-1369

Calzada MJ, Sipes JM, Krutzsch HC, Yurchenco PD, Annis DS, Mosher DF, Roberts DD (2003) Recognition of the N-terminal modules of thrombospondin-1 and thrombospondin-2 by alpha6beta1 integrin. J Biol Chem 278(42):40679-40687

Calzada MJ, Zhou L, Sipes JM, Zhang J, Krutzsch HC, Iruela-Arispe ML, Annis DS, Mosher DF, Roberts DD (2004) Alpha4beta1 integrin mediates selective endothelial cell responses to thrombospondins 1 and 2 in vitro and modulates angiogenesis in vivo. Circ Res 94(4):462-470

Casscells W, Bazoberry F, Speir E, Thompson N, Flanders K, Kondaiah P, Ferrans VJ, Epstein SE, Sporn M (1990) Transforming growth factor-beta 1 in normal heart and in myocardial infarction. Ann N Y Acad Sci 593:148-160

Chandrasekaran L, He CZ, Al-Barazi H, Krutzsch HC, Iruela-Arispe ML, Roberts DD (2000) Cell contact-dependent activation of alpha3betal integrin modulates endothelial cell responses to thrombospondin-1. Mol Biol Cell 11(9):2885-2900 
Chatila K, Ren G, Xia Y, Huebener P, Bujak M, Frangogiannis NG (2007) The role of the thrombospondins in healing myocardial infarcts. Cardiovasc Hematol Agents Med Chem 5(1):21-27

Chaulet H, Lin F, Guo J, Owens WA, Michalicek J, Kesteven SH, Guan Z, Prall OW, Mearns BM, Feneley MP, Steinberg SF, Graham RM (2006) Sustained augmentation of cardiac alpha1A-adrenergic drive results in pathological remodeling with contractile dysfunction, progressive fibrosis and reactivation of matricellular protein genes. J Mol Cell Cardiol 40 (4):540-552

Chen J, Somanath PR, Razorenova O, Chen WS, Hay N, Bornstein P, Byzova TV (2005) Akt1 regulates pathological angiogenesis, vascular maturation and permeability in vivo. Nat Med 11 (11):1188-1196

Cleutjens J, Huynen F, Smits J, Bornstein P, Daemen M (1999) Thrombospondin-2 deficiency in mice results in cardiac rupture early after myocardial infarction. Circ Res 100(Suppl):156

Collins AR, Schnee J, Wang W, Kim S, Fishbein MC, Bruemmer D, Law RE, Nicholas S, Ross RS, Hsueh WA (2004) Osteopontin modulates angiotensin II-induced fibrosis in the intact murine heart. J Am Coll Cardiol 43(9):1698-1705

Crabos M, Roth M, Hahn AW, Erne P (1994) Characterization of angiotensin II receptors in cultured adult rat cardiac fibroblasts. Coupling to signaling systems and gene expression. J Clin Invest 93(6):2372-2378

Crawford SE, Stellmach V, Murphy-Ullrich JE, Ribeiro SM, Lawler J, Hynes RO, Boivin GP, Bouck N (1998) Thrombospondin-1 is a major activator of TGF-beta1 in vivo. Cell 93(7):1159-1170

Dewald O, Ren G, Duerr GD, Zoerlein M, Klemm C, Gersch C, Tincey S, Michael LH, Entman ML, Frangogiannis NG (2004) Of mice and dogs: species-specific differences in the inflammatory response following myocardial infarction. Am J Pathol 164 (2):665-677

DiMichele LA, Doherty JT, Rojas M, Beggs HE, Reichardt LF, Mack CP, Taylor JM (2006) Myocyte-restricted focal adhesion kinase deletion attenuates pressure overload-induced hypertrophy. Circ Res 99(6):636-645

Dobaczewski M, Bujak M, Zymek P, Ren G, Entman ML, Frangogiannis NG (2006) Extracellular matrix remodeling in canine and mouse myocardial infarcts. Cell Tissue Res 324 (3): $475-488$

Donnini S, Morbidelli L, Taraboletti G, Ziche M (2004) ERK1-2 and p38 MAPK regulate MMP/TIMP balance and function in response to thrombospondin-1 fragments in the microvascular endothelium. Life Sci 74(24):2975-2985

Eghbali M, Tomek R, Sukhatme VP, Woods C, Bhambi B (1991) Differential effects of transforming growth factor-beta 1 and phorbol myristate acetate on cardiac fibroblasts. Regulation of fibrillar collagen mRNAs and expression of early transcription factors. Circ Res 69(2):483-490

Emonard H, Bellon G, Troeberg L, Berton A, Robinet A, Henriet P, Marbaix E, Kirkegaard K, Patthy L, Eeckhout Y, Nagase H, Hornebeck W, Courtoy PJ (2004) Low density lipoprotein receptor-related protein mediates endocytic clearance of proMMP-2.TIMP-2 complex through a thrombospondin-independent mechanism. J Biol Chem 279(52):54944-54951

Frangogiannis NG (2006) The mechanistic basis of infarct healing. Antioxid Redox Signal 8(11-12):1907-1939

Frangogiannis NG, Ren G, Dewald O, Zymek P, Haudek S, Koerting A, Winkelmann K, Michael LH, Lawler J, Entman ML (2005) Critical role of endogenous thrombospondin-1 in preventing expansion of healing myocardial infarcts. Circulation 111 (22):2935-2942

Gahtan V, Wang XJ, Ikeda M, Willis AI, Tuszynski GP, Sumpio BE (1999) Thrombospondin-1 induces activation of focal adhesion kinase in vascular smooth muscle cells. J Vasc Surg 29(6):10311036

Gao AG, Lindberg FP, Dimitry JM, Brown EJ, Frazier WA (1996) Thrombospondin modulates alpha $\mathrm{v}$ beta 3 function through integrin-associated protein. J Cell Biol 135(2):533-544

Gray MO, Long CS, Kalinyak JE, Li HT, Karliner JS (1998) Angiotensin II stimulates cardiac myocyte hypertrophy via paracrine release of TGF-beta 1 and endothelin-1 from fibroblasts. Cardiovasc Res 40(2):352-363

Gupta S, Das B, Sen S (2007) Cardiac hypertrophy: mechanisms and therapeutic opportunities. Antioxid Redox Signal 9(6):623-652

Hao J, Ju H, Zhao S, Junaid A, Scammell-La Fleur T, Dixon IM (1999) Elevation of expression of Smads 2, 3, and 4, decorin and TGF-beta in the chronic phase of myocardial infarct scar healing. J Mol Cell Cardiol 31(3):667-678

Heimer R, Bashey RI, Kyle J, Jimenez SA (1995) TGF-beta modulates the synthesis of proteoglycans by myocardial fibroblasts in culture. J Mol Cell Cardiol 27(10):2191-2198

Hein S, Arnon E, Kostin S, Schonburg M, Elsasser A, Polyakova V, Bauer EP, Klovekorn WP, Schaper J (2003) Progression from compensated hypertrophy to failure in the pressure-overloaded human heart: structural deterioration and compensatory mechanisms. Circulation 107(7):984-991

Heineke J, Molkentin JD (2006) Regulation of cardiac hypertrophy by intracellular signalling pathways. Nat Rev Mol Cell Biol 7 (8):589-600

Hudlicka O, Brown M, Egginton S (1992) Angiogenesis in skeletal and cardiac muscle. Physiol Rev 72(2):369-417

Ignarro LJ, Buga GM, Wood KS, Byrns RE, Chaudhuri G (1987) Endothelium-derived relaxing factor produced and released from artery and vein is nitric oxide. Proc Natl Acad Sci U S A 84 (24):9265-9269

Isenberg JS, Ridnour LA, Perruccio EM, Espey MG, Wink DA, Roberts DD (2005) Thrombospondin-1 inhibits endothelial cell responses to nitric oxide in a cGMP-dependent manner. Proc Natl Acad Sci U S A 102(37):13141-13146

Isenberg JS, Ridnour LA, Dimitry J, Frazier WA, Wink DA, Roberts DD (2006a) CD47 is necessary for inhibition of nitric oxidestimulated vascular cell responses by thrombospondin-1. J Biol Chem 281(36):26069-26080

Isenberg JS, Wink DA, Roberts DD (2006b) Thrombospondin-1 antagonizes nitric oxide-stimulated vascular smooth muscle cell responses. Cardiovasc Res 71(4):785-793

Isenberg JS, Frazier WA, Roberts DD (2008a) Thrombospondin-1: a physiological regulator of nitric oxide signaling. Cell Mol Life Sci 65:728-742

Isenberg JS, Roberts DD, Frazier WA (2008b) CD47: a new target in cardiovascular therapy. Arterioscler Thromb Vasc Biol 28 (4):615-621

Isenberg JS, Annis DS, Pendrak ML, Ptaszynska M, Frazier WA, Mosher DF, Roberts DD (2009a) Differential interactions of thrombospondin-1, -2 , and -4 with CD47 and effects on cGMP signaling and ischemic injury responses. J Biol Chem 284 (2):1116-1125

Isenberg JS, Qin Y, Maxhimer JB, Sipes JM, Despres D, Schnermann J, Frazier WA, Roberts DD (2009b) Thrombospondin-1 and CD47 regulate blood pressure and cardiac responses to vasoactive stress. Matrix Biol 28(2):110-119

Karch R, Neumann F, Ullrich R, Neumuller J, Podesser BK, Neumann M, Schreiner W (2005) The spatial pattern of coronary capillaries in patients with dilated, ischemic, or inflammatory cardiomyopathy. Cardiovasc Pathol 14(3):135-144

Koch W, Hoppmann P, Waha AD, Schomig A, Kastrati A (2008) Polymorphisms in thrombospondin genes and myocardial infarction: a case-control study and a meta-analysis of available evidence. Hum Mol Genet 17:1120-1126 
Krady MM, Zeng J, Yu J, MacLauchlan S, Skokos EA, Tian W, Bornstein P, Sessa WC, Kyriakides TR (2008) Thrombospondin2 modulates extracellular matrix remodeling during physiological angiogenesis. Am J Pathol 173(3):879-891

Krutzsch HC, Choe BJ, Sipes JM, Guo N, Roberts DD (1999) Identification of an alpha(3)beta(1) integrin recognition sequence in thrombospondin-1. J Biol Chem 274(34):24080-24086

Kyriakides TR, Zhu YH, Smith LT, Bain SD, Yang Z, Lin MT, Danielson KG, Iozzo RV, LaMarca M, McKinney CE, Ginns EI, Bornstein P (1998) Mice that lack thrombospondin 2 display connective tissue abnormalities that are associated with disordered collagen fibrillogenesis, an increased vascular density, and a bleeding diathesis. J Cell Biol 140(2):419-430

Kyriakides TR, Tam JW, Bornstein P (1999) Accelerated wound healing in mice with a disruption of the thrombospondin 2 gene. J Invest Dermatol 113(5):782-787

Lal H, Verma SK, Foster DM, Golden HB, Reneau JC, Watson LE, Singh H, Dostal DE (2009) Integrins and proximal signaling mechanisms in cardiovascular disease. Front Biosci 14:23072334

Lamy L, Foussat A, Brown EJ, Bornstein P, Ticchioni M, Bernard A (2007) Interactions between CD47 and thrombospondin reduce inflammation. J Immunol 178(9):5930-5939

Lange-Asschenfeldt B, Weninger W, Velasco P, Kyriakides TR, von Andrian UH, Bornstein P, Detmar M (2002) Increased and prolonged inflammation and angiogenesis in delayed-type hypersensitivity reactions elicited in the skin of thrombospondin2-deficient mice. Blood 99(2):538-545

Lee T, Esemuede N, Sumpio BE, Gahtan V (2003) Thrombospondin-1 induces matrix metalloproteinase-2 activation in vascular smooth muscle cells. J Vasc Surg 38(1):147-154

Lijnen PJ, Petrov VV, Fagard RH (2000) Induction of cardiac fibrosis by transforming growth factor-beta(1). Mol Genet Metab 71(12):418-435

Lu H, Fedak PW, Dai X, Du C, Zhou YQ, Henkelman M, Mongroo PS, Lau A, Yamabi H, Hinek A, Husain M, Hannigan G, Coles JG (2006) Integrin-linked kinase expression is elevated in human cardiac hypertrophy and induces hypertrophy in transgenic mice. Circulation 114(21):2271-2279

Maclauchlan S, Skokos EA, Agah A, Zeng J, Tian W, Davidson JM, Bornstein P, Kyriakides TR (2009) Enhanced angiogenesis and reduced contraction in thrombospondin-2-null wounds is associated with increased levels of matrix metalloproteinases- 2 and -9 , and soluble VEGF. J Histochem Cytochem 57(4):301-313

Malek MH, Olfert Ph DI (2009) Global deletion of thrombospondin-1 increases cardiac and skeletal muscle capillarity and exercise capacity in mice. Exp Physiol 94:749-760

Manso AM, Elsherif L, Kang SM, Ross RS (2006) Integrins, membranetype matrix metalloproteinases and ADAMs: potential implications for cardiac remodeling. Cardiovasc Res 69(3):574-584

Miyata S, Haneda T (1994) Hypertrophic growth of cultured neonatal rat heart cells mediated by type 1 angiotensin II receptor. Am J Physiol 266(6 Pt 2):H2443-2451

Mustonen E, Aro J, Puhakka J, Ilves M, Soini Y, Leskinen H, Ruskoaho H, Rysa J (2008) Thrombospondin-4 expression is rapidly upregulated by cardiac overload. Biochem Biophys Res Commun 373(2):186-191

Qian X, Wang TN, Rothman VL, Nicosia RF, Tuszynski GP (1997) Thrombospondin-1 modulates angiogenesis in vitro by upregulation of matrix metalloproteinase- 9 in endothelial cells. Exp Cell Res 235(2):403-412

Rastaldo R, Pagliaro P, Cappello S, Penna C, Mancardi D, Westerhof N, Losano G (2007) Nitric oxide and cardiac function. Life Sci 81(10):779-793

Ridnour LA, Isenberg JS, Espey MG, Thomas DD, Roberts DD, Wink DA (2005) Nitric oxide regulates angiogenesis through a functional switch involving thrombospondin-1. Proc Natl Acad Sci U S A 102(37):13147-13152

Rodriguez-Manzaneque JC, Lane TF, Ortega MA, Hynes RO, Lawler J, Iruela-Arispe ML (2001) Thrombospondin-1 suppresses spontaneous tumor growth and inhibits activation of matrix metalloproteinase-9 and mobilization of vascular endothelial growth factor. Proc Natl Acad Sci U S A 98(22):1248512490

Rosenkranz S (2004) TGF-betal and angiotensin networking in cardiac remodeling. Cardiovasc Res 63(3):423-432

Rysa J, Leskinen H, Ilves M, Ruskoaho H (2005) Distinct upregulation of extracellular matrix genes in transition from hypertrophy to hypertensive heart failure. Hypertension 45(5):927-933

Sappino AP, Schurch W, Gabbiani G (1990) Differentiation repertoire of fibroblastic cells: expression of cytoskeletal proteins as marker of phenotypic modulations. Lab Invest 63(2):144-161

Schellings MW, Pinto YM, Heymans S (2004) Matricellular proteins in the heart: possible role during stress and remodeling. Cardiovasc Res 64(1):24-31

Schellings MW, Vanhoutte D, Swinnen M, Cleutjens JP, Debets J, van Leeuwen RE, d'Hooge J, Van de Werf F, Carmeliet P, Pinto YM, Sage EH, Heymans S (2009) Absence of SPARC results in increased cardiac rupture and dysfunction after acute myocardial infarction. J Exp Med 206(1):113-123

Schiller M, Javelaud D, Mauviel A (2004) TGF-beta-induced SMAD signaling and gene regulation: consequences for extracellular matrix remodeling and wound healing. J Dermatol Sci 35(2):83-92

Schorb W, Booz GW, Dostal DE, Conrad KM, Chang KC, Baker KM (1993) Angiotensin II is mitogenic in neonatal rat cardiac fibroblasts. Circ Res 72(6):1245-1254

Schroen B, Heymans S, Sharma U, Blankesteijn WM, Pokharel S, Cleutjens JP, Porter JG, Evelo CT, Duisters R, van Leeuwen RE, Janssen BJ, Debets JJ, Smits JF, Daemen MJ, Crijns HJ, Bornstein P, Pinto YM (2004) Thrombospondin-2 is essential for myocardial matrix integrity: increased expression identifies failure-prone cardiac hypertrophy. Circ Res 95(5):515-522

Schultz-Cherry S, Chen H, Mosher DF, Misenheimer TM, Krutzsch HC, Roberts DD, Murphy-Ullrich JE (1995) Regulation of transforming growth factor-beta activation by discrete sequences of thrombospondin 1. J Biol Chem 270(13):7304-7310

Shai SY, Harpf AE, Babbitt CJ, Jordan MC, Fishbein MC, Chen J, Omura M, Leil TA, Becker KD, Jiang M, Smith DJ, Cherry SR, Loftus JC, Ross RS (2002) Cardiac myocyte-specific excision of the betal integrin gene results in myocardial fibrosis and cardiac failure. Circ Res 90(4):458-464

Shimazaki M, Nakamura K, Kii I, Kashima T, Amizuka N, Li M, Saito M, Fukuda K, Nishiyama T, Kitajima S, Saga Y, Fukayama M, Sata M, Kudo A (2008) Periostin is essential for cardiac healing after acute myocardial infarction. J Exp Med 205(2): 295-303

Shiojima I, Sato K, Izumiya Y, Schiekofer S, Ito M, Liao R, Colucci WS, Walsh K (2005) Disruption of coordinated cardiac hypertrophy and angiogenesis contributes to the transition to heart failure. J Clin Invest 115(8):2108-2118

Simantov R, Silverstein RL (2003) CD36: a critical anti-angiogenic receptor. Front Biosci 8:s874-882

Simantov R, Febbraio M, Silverstein RL (2005) The antiangiogenic effect of thrombospondin-2 is mediated by CD36 and modulated by histidine-rich glycoprotein. Matrix Biol 24(1):27-34

Spinale FG (2007) Myocardial matrix remodeling and the matrix metalloproteinases: influence on cardiac form and function. Physiol Rev 87(4):1285-1342

Staniszewska I, Zaveri S, Del Valle L, Oliva I, Rothman VL, Croul SE, Roberts DD, Mosher DF, Tuszynski GP, Marcinkiewicz C (2007) Interaction of alpha9beta1 integrin with thrombospondin-1 promotes angiogenesis. Circ Res 100(9):1308-1316 
Sun J, Hopkins BD, Tsujikawa K, Perruzzi C, Adini I, Swerlick RA, Bornstein P, Lawler J, Benjamin LE (2009) Thrombospondin-1 modulates Vegf-a mediated Akt signaling and capillary survival in the developing retina. Am J Physiol Heart Circ Physiol 296: H1344-H1351

Swynghedauw B (1999) Molecular mechanisms of myocardial remodeling. Physiol Rev 79(1):215-262

Takahashi N, Calderone A, Izzo NJ Jr, Maki TM, Marsh JD, Colucci WS (1994) Hypertrophic stimuli induce transforming growth factor-beta 1 expression in rat ventricular myocytes. J Clin Invest 94(4):1470-1476

Tan FL, Moravec CS, Li J, Apperson-Hansen C, McCarthy PM, Young JB, Bond M (2002) The gene expression fingerprint of human heart failure. Proc Natl Acad Sci U S A 99(17):11387-11392

Taraboletti G, Morbidelli L, Donnini S, Parenti A, Granger HJ, Giavazzi R, Ziche M (2000) The heparin binding $25 \mathrm{kDa}$ fragment of thrombospondin-1 promotes angiogenesis and modulates gelatinase and TIMP-2 production in endothelial cells. FASEB J 14(12):1674-1676

Thompson NL, Bazoberry F, Speir EH, Casscells W, Ferrans VJ, Flanders KC, Kondaiah P, Geiser AG, Sporn MB (1988) Transforming growth factor beta-1 in acute myocardial infarction in rats. Growth Factors 1(1):91-99

Tokuda K, Kai H, Kuwahara F, Yasukawa H, Tahara N, Kudo H, Takemiya K, Koga M, Yamamoto T, Imaizumi T (2004) Pressure-independent effects of angiotensin II on hypertensive myocardial fibrosis. Hypertension 43(2):499-503

Tomasek JJ, Gabbiani G, Hinz B, Chaponnier C, Brown RA (2002) Myofibroblasts and mechano-regulation of connective tissue remodelling. Nat Rev Mol Cell Biol 3(5):349-363

Tomita H, Egashira K, Ohara Y, Takemoto M, Koyanagi M, Katoh M, Yamamoto H, Tamaki K, Shimokawa H, Takeshita A (1998) Early induction of transforming growth factor-beta via angiotensin II type 1 receptors contributes to cardiac fibrosis induced by long-term blockade of nitric oxide synthesis in rats. Hypertension 32(2): 273-279

Topol EJ, McCarthy J, Gabriel S, Moliterno DJ, Rogers WJ, Newby LK, Freedman M, Metivier J, Cannata R, O'Donnell CJ, KottkeMarchant K, Murugesan G, Plow EF, Stenina O, Daley GQ (2001) Single nucleotide polymorphisms in multiple novel thrombospondin genes may be associated with familial premature myocardial infarction. Circulation 104(22):2641-2644

Trueblood NA, Xie Z, Communal C, Sam F, Ngoy S, Liaw L, Jenkins AW, Wang J, Sawyer DB, Bing OH, Apstein CS, Colucci WS, Singh K (2001) Exaggerated left ventricular dilation and reduced collagen deposition after myocardial infarction in mice lacking osteopontin. Circ Res 88(10):1080-1087

Vasan RS, Benjamin EJ, Levy D (1995) Prevalence, clinical features and prognosis of diastolic heart failure: an epidemiologic perspective. J Am Coll Cardiol 26(7):1565-1574

Villarreal FJ, Dillmann WH (1992) Cardiac hypertrophy-induced changes in mRNA levels for TGF-beta 1, fibronectin, and collagen. Am J Physiol 262(6 Pt 2):H1861-1866

Villarreal FJ, Kim NN, Ungab GD, Printz MP, Dillmann WH (1993) Identification of functional angiotensin II receptors on rat cardiac fibroblasts. Circulation 88(6):2849-2861

Villarreal FJ, Lee AA, Dillmann WH, Giordano FJ (1996) Adenovirus-mediated overexpression of human transforming growth factor-beta 1 in rat cardiac fibroblasts, myocytes and smooth muscle cells. J Mol Cell Cardiol 28(4):735-742

Wang D, Oparil S, Feng JA, Li P, Perry G, Chen LB, Dai M, John SW, Chen YF (2003) Effects of pressure overload on extracellular matrix expression in the heart of the atrial natriuretic peptide-null mouse. Hypertension 42(1):88-95

Wang XJ, Maier K, Fuse S, Willis AI, Olson E, Nesselroth S, Sumpio BE, Gahtan V (2008) Thrombospondin-1-induced migration is functionally dependent upon focal adhesion kinase. Vasc Endovascular Surg 42(3):256-262

Weir RA, McMurray JJ, Velazquez EJ (2006) Epidemiology of heart failure and left ventricular systolic dysfunction after acute myocardial infarction: prevalence, clinical characteristics, and prognostic importance. Am J Cardiol 97(10A):13F-25F

White DE, Coutu P, Shi YF, Tardif JC, Nattel S, St Arnaud R, Dedhar S, Muller WJ (2006) Targeted ablation of ILK from the murine heart results in dilated cardiomyopathy and spontaneous heart failure. Genes Dev 20(17):2355-2360

Wunsch M, Sharma HS, Markert T, Bernotat-Danielowski S, Schott RJ, Kremer P, Bleese N, Schaper W (1991) In situ localization of transforming growth factor beta 1 in porcine heart: enhanced expression after chronic coronary artery constriction. J Mol Cell Cardiol 23(9):1051-1062

Yang Z, Kyriakides TR, Bornstein P (2000) Matricellular proteins as modulators of cell-matrix interactions: adhesive defect in thrombospondin 2-null fibroblasts is a consequence of increased levels of matrix metalloproteinase-2. Mol Biol Cell 11(10):33533364

Yang Z, Strickland DK, Bornstein P (2001) Extracellular matrix metalloproteinase 2 levels are regulated by the low density lipoprotein-related scavenger receptor and thrombospondin 2 . J Biol Chem 276(11):8403-8408 